\title{
Paweł Kocoń
}

\author{
Uniwersytet Ekonomiczny w Katowicach \\ Wydział Ekonomii \\ e-mail: pawel.kocon@ue.katowice.pl
}

\section{Sądy wojskowe - uwarunkowania komunikacji z otoczeniem}

Kody JEL: M3, F5, L3

Słowa kluczowe: sądownictwo, komunikacja, wojsko, otoczenie, strategia

Streszczenie. Sądownictwo wojskowe wydaje się być zapomnianym i pomijanym rodzajem wymiaru sprawiedliwości, mimo że jego istnienie gwarantuje konstytucja RP. Sądy te są specyficzną, wyspecjalizowaną częścią sądownictwa, zajmującą się żołnierzami i cywilnymi pracownikami wojska. W dobie zagrożenia terroryzmem oraz wojen hybrydowych, to na sądach wojskowych szczególnie ciąży obowiązek właściwego wyjaśniania ferowanych wyroków. Celem komunikacji jest realizacja strategii organizacyjnej sądów, zakładającej efektywne i sprawiedliwe sądzenie przy zapewnieniu prawnych i materialnych warunków ku temu. Można takie warunki osiągnąć dzięki rzetelnej komunikacji sądów z interesariuszami. Bez komunikowania się z nimi brakuje odzewu w postaci nadawania uprawnień czy dzielenia się przez interesariuszy innymi zasobami. Celem artykułu jest identyfikacja wybranych czynników, wpływających na komunikację sądów wojskowych z otoczeniem. Zastosowana metoda badawcza to analiza dokumentacji.

\section{Wprowadzenie}

Sądy wojskowe są specyficzną, wyspecjalizowaną częścią sądownictwa, zajmującą się żołnierzami w służbie czynnej. Są jedną z części klasycznego trójpodziału władzy; warto przy tym wspomnieć jeden z warunków jej egzystowania - w Polsce władza sądownicza jest nie tylko niezależna, ale $\mathrm{i}$ autonomiczna. 
Oznacza to, że społeczeństwo ma ograniczony wpływ na wybór sędziów, a tym samym na kształtowanie podejścia we wdrażaniu przyjętego modelu ich działania. Nie oznacza to, że sądy i sędziowie nie muszą prawidłowo komunikować się z szeroko rozumianym otoczeniem swojej organizacji. Wprost przeciwnie, w dobie zagrożenia terroryzmem oraz wojen hybrydowych, to na sądach wojskowych szczególnie ciąży obowiązek właściwego wyjaśniania ferowanych wyroków, tak aby zostały zrozumiane przez interesariuszy, m.in. członków społeczeństwa.

Charles Cooley określił komunikowanie jako swego rodzaju mechanizm, dzięki któremu stosunki międzyludzkie istnieją i rozwijają się, a wytworzone przez umysł ludzkie symbole są przekazywane w przestrzeni i zachowywane w czasie (Dobek-Ostrowska, 1999, s. 12). Jak pisze Ewa M. Cenker, komunikacja to społeczne działanie polegające na wymianie informacji co najmniej między dwoma członkami instytucjonalnego systemu stosunków (społecznego, międzyludzkiego) (Cenker, 2000, s. 68). Celem tej komunikacji jest realizacja strategii organizacyjnej sądów wojskowych, czego podstawą są efektywne i sprawiedliwe sądzenie przy zapewnieniu prawnych i materialnych warunków ku temu. Można takie warunki osiągnąć, jeśli jednym ze spełnianych będzie zasada rzetelnego komunikowania się sądów z interesariuszami.

Celem artykułu jest ukazanie wybranych czynników decydujących o tym, w jakich warunkach odbywa się komunikacja sądów wojskowych $\mathrm{z}$ otoczeniem. Wyróżniono dwa podstawowe zbiory uwarunkowań - pierwsza grupa to uwarunkowania prawne - wymogi strategiczne Military Public Affairs, czyli standardy public relations sił zbrojnych, a w wypadku Polski - standardy NATO. Druga $\mathrm{z}$ grup czynników to uwarunkowania militarne komunikacji, wynikające z przynależności sądów wojskowych do polskich sił zbrojnych.

Zastosowana metoda badawcza to analiza dokumentacji. Analizowano przede wszystkim przepisy prawne dotyczące sądów wojskowych, instrukcje Paktu Północnoatlantyckiego i polskie dokumenty dotyczące komunikowania sił zbrojnych $\mathrm{z}$ otoczeniem.

Z przeprowadzonej analizy wynika, że o ile stosowane akty prawne i dokumenty organizują formę komunikowania, wytyczne oparte są na zakazach, wydaje się, że brakuje polecania pozytywnych form ukształtowanego podejścia, a wskazówki pozostają ogólne i nie w pełni odpowiadające na potrzeby współczesnych wymagań.

\section{Uwarunkowania prawne komunikowania się sadów wojskowych z otoczeniem}

Jednym z najistotniejszych dokumentów, kształtujących podmiotowość sądów wojskowych jest Konstytucja Rzeczpospolitej Polskiej. W artykule 175 ust. 1 
Konstytucji RP wymienia się sądy wojskowe. Art. 45 Konstytucji nadaje im tak jak wszystkim pozostałym sądom - prawo do niezależności i niezawisłości.

Sądy wojskowe orzekają w sprawach żołnierzy w czynnej służbie wojskowej o przestępstwa popełnione w czasie pełnienia tej służby.(Hofmański, Sadzik, Zgryzek, 2004, s. 587; Grzegorczyk, 2004, s. 1603). Oznacza to, że jak pisze Sławomir Steinborn (2006), że do nich kierowane są przestępstwa, które popełnione zostały przez żołnierzy w służbie czynnej (za wyjątkiem tych czynów, które dokonane zostały na szkodę osoby, która nie jest żołnierzem):

- podczas lub w związku z pełnieniem obowiązków służbowych,

- w obrębie obiektu wojskowego lub wyznaczonego miejsca przebywania,

- na szkodę wojska,

- $\quad$ z naruszeniem obowiązku wynikającego ze służby wojskowe.

Nadzór nad sądami wojskowymi sprawuje zarówno Ministerstwo Sprawiedliwości, jak i Ministerstwo Obrony Narodowej. Co ważne, na mocy art. 4 Ustawy z 21 sierpnia 1997 roku Prawo o ustroju sądów wojskowych (Dz.U. 1997, nr 117, poz. 753), działalność sądów wojskowych jest finansowana ze środków budżetowych Ministerstwa Obrony Narodowej.

Analiza wspomnianych aktów prawnych, pozwala zauważyć, że brak w nich odwołań do komunikacji z otoczeniem. Za jedyne odwołanie do tzw. corporate design można jedynie uznać art. 25. § 1. Ustawy Prawo o ustroju sądów wojskowych, w którym określono ubiór sędziów i ławników, który jest toga, a sędziego przewodniczącego na rozprawie - także ,nakładany na kołnierz togi łańcuch z wizerunkiem orła" (Ustawa z dnia 21 sierpnia..., art. 25. § 1). Można przyznać, że jest to jedyne odniesienie, pośrednie zresztą, do warunków komunikowania się - tego aspektu działalności sądów wojskowych nie poddano szczegółowym uregulowaniom w ustawie.

Podstawowym aspektem komunikacji, który poddano regulacjom prawnym, w przypadku polskich sadów, są zasady dotyczące metod komunikacji organizacji publicznych, które uszczegóławia art. 61 Konstytucji o dostępie obywateli do informacji. Generalną zasadą konstytucyjną jest dostęp obywatela do informacji związanych z działaniem rządu, samorządów, a także sadownictwa wraz z możliwością ich rejestrowania i przechowywania. Nieliczne wyjątki od tego działania dotyczą bezpieczeństwa i wolności osobistych. Ustawa z dnia 6 września 2001 roku o dostępie do informacji publicznej (Dz.U. 2001, nr 112, poz. 1198) reguluje warunki dostępu obywateli do tego typu kwestii. Komunikowanie polskich sił zbrojnych i sądów wojskowych reguluje również Ustawa z dnia 26 stycznia 1984 roku Prawo prasowe (Dz.U. 1984, nr 5, poz. 24) - wojsko, czyli i sądy wojskowe, mają obowiązek zamieszczania informacji w biuletynie informacji publicznej. 
Wydaje się, że nacisk legislacyjny położono na sam fakt dostępności czy też umożliwienia stworzenia kanału komunikacyjnego sądu z jego interesariuszami, wszelako bez uszczegóławiania zasad, jakie tą komunikacją rządzą, czy też wskazówek, jak powinna być ona prowadzona. O ile obowiązek stworzenia i uzupełniania biuletynu może zostać uznany za wskazanie kanału komunikacji, trudno przyjąć, że powinien pozostać on jedyną dostępną czy też aprobowaną formą przekazywania informacji między sądem a jego otoczeniem

\section{Uwarunkowania komunikacji sądów wojskowych z otoczeniem wynikające z przynależności do polskich sil zbrojnych}

Stosując podział na uwarunkowania prawne i militarne, należy zdawać sobie sprawę z tego, że jest to podział nieprecyzyjny. Siły zbrojne, jak każda organizacja publiczna, kierują się w swych działaniach prawem krajowym i międzynarodowym, niemniej jednak istnieje pewna granica pomiędzy przepisami prawa, dotyczącymi orzekania w sądach wojskowych i powiadamiania o wyrokach społeczeństwo, a instrukcjami i rozkazami dotyczącymi jednostek wojskowych.

Istnieje obszar wojskowego public relations, regulowanego (w krajach stowarzyszonych) normami NATO i wewnętrznymi dyrektywami państw. Według polskiego Ministerstwa Obrony Narodowej public relations definiuje się następująco: „świadoma organizacja komunikowania poprzez podtrzymywanie wzajemnych relacji instytucji z otoczeniem, władz instytucji z pracownikami, instytucji z mediami, mająca na celu wykreowanie pożądanego wizerunku instytucji w oczach opinii publicznej, społeczeństwa. Integralną rolę w działaniach public relations odgrywa informacja - wiarygodna, obiektywna, fachowa, kompetentna i otwarta wobec mediów. Informowanie odbiorców przez instytucję o swoich zamierzeniach, planach, aktualnych działaniach, jest elementem świadomej, długofalowej strategii, funkcją strategicznego zarządzania instytucją. W ujęciu zadaniowym koncentruje się na gromadzeniu, analizie, przetwarzaniu i wytwarzaniu oraz dystrybucji/upowszechnianiu komunikatów w przestrzeni publicznej (adresowanych do określonych grup docelowych)" (Decyzja..., s. 15). Warto zauważyć, że wojskowe public relations, dzięki rzetelnej, prawdziwej informacji odcina się od możliwości potencjalnej manipulacji danymi, co, jak się wydaje, często towarzyszy przekazywaniu informacji.

Mówiąc o public relations, nie sposób nie zauważyć pewnej sprzeczności czy kolizji semantycznej. Wojskowe public relations, zgodnie z dokumentami NATO (NATO Military..., 2011) nazywane jest Military Public Affairs (Głuszczak, 2012). Tym samym, nazwa tego narzędzia w naukach o zarządzaniu nie jest do końca spójna z nazwą wykorzystywaną w naukach o wojskowości. Zakres obu pojęć również nie do końca jest tożsamy, mimo ich wymiennego stosowania na styku tych dwóch pól badawczych. 
Misją wojskowego public affairs NATO jest wspieranie dowódców przez przekazywanie odbiorcom na czas dokładnych informacji, w celu poprawienia publicznej świadomości i zrozumienia militarnych aspektów funkcjonowania sojuszu, wzmacniając w ten sposób wiarygodność organizacji. Odbiorcami mogą być sojusznicy międzynarodowi, regionalni, lokalni czy wewnętrzni - ze względu na podejmowany problem lub działalność (NATO Military..., 2011).

Podstawową jednostką w ramach NATO, odpowiadającą za standardy komunikacyjne jest AC (Allied Command Operation), czyli Dowództwo Sił Sojuszniczych NATO ds. Operacji „Strategic Communications” (ACO..., 2008). Głównym zadaniem takiej komunikacji strategicznej jest przeciwdziałanie realizacji strategii informacyjnych przeciwników, co objawia się we wspomaganiu operacji, jak i zajmowaniu się jej publiczną percepcją. Zadania ACO określone są jako( $A C O \ldots, 2008)$ :

1. Aktywne uczestniczenie w procesie tworzenia informacji.

2. Szybkie upowszechnianie informacji w ogólnodostępnym i łatwo zrozumiałym formacie.

3. Gwarantowanie, że informacje będą regularnie monitorowane, dostosowywane i uaktualniane.

4. Poszukiwanie możliwości rozpowszechniania informacji w środowisku informacyjnym 24/7.

5. Słuchanie kluczowych odbiorców i odpowiadanie im poprzez wyjaśnianie bądź usprawiedliwianie (uzasadnianie) decyzji; kierowanie się zasadami etyki.

Zadania te nie odbiegają znacząco od zadań „cywilnego” public relations; co wynika z wyznaczenia operacyjności zadania działalności informacyjnej sądów wojskowych, które na mocy powyższych instrukcji w swoich działaniach komunikacyjnych upodabniają się do sądów cywilnych. Co za tym idzie, każda z kwater NATO wyłania osobę, która pełni dwie role:

- oficjalną - to osoba, która ze względu na pozycję lub mianowanie jest wyznaczona do kontaktów z mediami,

- wyznaczoną - to osoba, która komunikuje się wewnętrznie lub na zewnątrz w sprawach NATO, ze względu na charakter jej obowiązków; jest to zazwyczaj ekspert w danej dziedzinie (NATO Military ..., 2011).

Można przyjąć, że tym samym wskazany jest drugi powszechnie akceptowany, obok biuletynu, kanał stałej komunikacji sądu z jego interesariuszami osoba bezpośrednio wyznaczona do przekazywania komunikatów i prezentowania stanowiska szerszemu gronu zainteresowanych.

Warto zauważyć, że formą kształtowania metod podejmowania komunikacji jest system oparty na zakazach pewnych form komunikacji, ze wskazaniem na ryzyko, jakie niosą, natomiast nie wskazuje się, z podobnym naciskiem, form poprawnych czy też zalecanych metod komunikacji. O ile takie podejście może 
pomóc uniknąć zachowań potencjalnie niezręcznych dla organizacji, trudno mówić w takim układzie o tworzeniu wzorca najwłaściwszych zachowań i najbardziej skutecznych rozwiązań, co z pewnością usprawniłoby korzystanie $\mathrm{z}$ tego kanału komunikacyjnego i, być może, ułatwiłoby pracę zaangażowanym osobom.

W przypadku NATO, podręcznikiem wyznaczającym standardy komunikowania jest Handbook (2014). Nie zawarto w nim informacji przeznaczonych dla sądów wojskowych, ale zaprezentowano ogólne wskazówki dotyczące komunikowania organizacji wojskowych $\mathrm{z}$ otoczeniem. Jest więc to, może nie narzędzie, ale pewna pomoc w tworzeniu standardów komunikowania się określonej jednostki sądowej. Co również istotne, utrzymywanie relacji opartych na tych instrukcjach zapewnia mediom możliwość stałego otrzymywania informacji o NATO. Być może zatem, ze strony organizacji wojskowych, takich jak m.in. sądy wojskowe praca $z$ mediami powinna polegać na rozwijaniu stosunków z lokalnymi dziennikarzami i utrzymywaniu z nimi regularnego kontaktu.

W Polsce podejmowane są próby stworzenia nowoczesnego systemu komunikowania wojska ze społeczeństwem. Jego elementem było powstanie Centrum Informacyjnego MON w 2004 roku, którego kontynuacją jest Departament Prasowo-Informacyjny MON, działający od 1 stycznia 2007 roku. Kompetencje osoby odpowiadającej za ten departament, na stanowisku dyrektora, skupiają się na nadzorze merytorycznym nad działalnością służby prasowej, wliczając $\mathrm{w}$ to Wojskowy Instytut Wydawniczy w Warszawie. Dyrektor jest również odpowiedzialny na tworzenie oraz wprowadzanie zasad i kierunków polityki informacyjnej resortu oraz zapewnia prowadzenie polityki informacyjnej, odpowiadającej okolicznościom, potrzebom i zainteresowaniom opinii publicznej (Decyzja $\mathrm{nr} 108 . . ., 2009$ ).

Pewnym problem jest brak osoby odpowiadającej za komunikację sądów wojskowych z otoczeniem. Co prawda, każdy okręgowy sąd wojskowy ma swojego rzecznika prasowego, ale brakuje osoby, tworzącej standardy komunikacji elektronicznej i jednakowe wzorce dla wszystkich podmiotów.

Wszystkie powyższe dokumenty wyznaczają standard profesjonalnego komunikowania sądów z otoczeniem. Dalszych badań wymaga, na ile te standardy wdrożono oraz, co wydaje się najistotniejsze, czy wdrożone podejście odpowiada rzeczywistym wyzwaniom komunikacyjnym tych jednostek.

\section{Podsumowanie}

Same dokumenty poparte nawet zobowiązaniem ich wdrożenia, nie gwarantują skuteczności komunikowania. Z drugiej strony, jakość komunikowania może świadczyć o wdrożeniu lub niewdrożeniu właściwych standardów. Przed sądami wojskowymi stoją duże wyzwania - terroryzm i wojny hybrydowe to nie tylko sprawy z trudnym ustaleniem winy oskarżonych oraz wymiaru kary, ale 
z powodu częstego maskowania mocodawcy, kiedy do winy przyznają się niewinne osoby lub organizacje, problem polega na prawidłowym rozpoznaniu właściwości sądów, tj. uzasadnieniu, że to akurat sądy wojskowe mogą sądzić np. terrorystów.

Wszystkie tego typu rozstrzygnięcia budzą ogromne społeczne emocje. Zabicie afgańskich cywili w Nanghar Khel poruszają opinię publiczną, a wyroki zarówno skazujące, jak i uniewinniające są szeroko krytykowane, stąd konieczność właściwego wyjaśniania publiczności działalności sądów wojskowych. Aby wyjaśnienie takie było pełne, należy zbadać działania komunikacyjne Sił Zbrojnych Rzeczpospolitej Polski oraz dyskurs na temat bezpieczeństwa narodowego. Warto zaznaczyć, że jakość dyskursu na temat wojskowego sądownictwa jest po części wypadkową jakości komunikowania agend wojskowych i cywilnych, odpowiedzialnych za komunikowanie wojska i wymiaru sprawiedliwości, a nieodnoszących się do sądów wojskowych.

Podstawowe uwarunkowania komunikowania sądów wojskowych z otoczeniem to przepisy prawne - tyle tylko, że stosowne akty prawne nie regulują komunikacji sądów wojskowych $\mathrm{z}$ otoczeniem. Pozostają instrukcje NATO i stosowne dokumenty Ministerstwa Obrony Narodowej, regulujące kwestie komunikowania sił zbrojnych z otoczeniem - te jednak nie odnoszą się do specyficznej organizacji, jaką są sądy wojskowe. Komunikowanie sądów wojskowych $\mathrm{z}$ otoczeniem polega zatem w pewnym stopniu na improwizacji, a brak gotowych wytycznych/wzorów, niepolegających jedynie na zakazach, wydłuża proces uczenia się przedstawicieli instytucji o właściwych metodach funkcjonowania w kanale komunikacyjnym dowolnego typu.

\section{Bibliografia}

ACO Strategic communications (2008). Directive Number 95-2, September. Pobrano z: http://Indianstrategicknowledgeonline.com/web/NATOstratcom_15sep2008.pdf (1.03.15).

Cenker, M.E. (2000). Public relations. Poznań: Wydawnictwo Wyższej Szkoły Bankowej.

Decyzja nr 108/MON Ministra Obrony Narodowej z dnia 7 kwietnia 2009 r. w sprawie zasad realizacji polityki informacyjnej w resorcie obrony narodowej. Dz. Urz. 2009, nr 7, poz. 82.

Decyzja nr 274/MON z dnia 6 lipca 2006 r. w sprawie wprowadzenia do użytku „Strategii informowania i promocji obronności resortu Obrony Narodowej”, Dz. Urz. 2006, nr 13. Pobrano z: http://biuletyn.mon.gov.pl/pliki/File/Dz_Urz_MON/2006pdf/Dz\%20U\%20Nr\%2013.06.pdf.

Dobek-Ostrowska, B. (1999). Podstawy komunikowania społecznego. Wrocław: Wydawnictwo Astrum.

Głuszczak, S. (2012). Oficer Prasowy - wojskowy PRowiec. Pobrano z: www.proto.pl/PR/Pdf/ Oficer_prasowy_wojskowy_PR-owiec.pdf.

Grzegorczyk, T, (2014). Kodeks postepowania karnego. Komentarz. Kraków: Wolters Kluwer.

Handbook Public Affairs (2014). NATO/OCTAN/ Allied command operations and alliend command transformation. Pobrano z: https://www.shape.nato.int/systems/file_download.ashx? $\mathrm{pg}=15767 \&$ ver $=2$.

Hofmański, P, Sadzik, E, Zgryzek, K. (2004). Kodeks postępowania karnego. Komentarz, t. 3. Warszawa: C.H. Beck. 
Konstytucja Rzeczpospolitej Polskiej z dnia 2 kwietnia 1997. Dz.U. 1997, nr 78, poz. 483.

NATO Military Public Affairs Policy (2011). MC 0457/2. February. Pobrano z: www.nato.int/ ims/docu/mil-pol-pub-affairs-en.pdf

Steinborn, S. (2006). W sprawie optymalnego zakresu jurysdykcji sądów wojskowych. Prokuratura i Prawo, 7 (8), 59-80.

Ustawa z dnia 21 sierpnia 1997 r. Prawo o ustroju sądów wojskowych. Dz.U. 1997, nr 117, poz. 753. Pobrano z: http://isap.sejm.gov.pl/DetailsServlet?id=WDU19971170753.

Ustawa z dnia 26 stycznia 1984 r. Prawo prasowe. Dz.U. 1984, nr 5, poz. 24)

Ustawa $z$ dnia 6 września 2001 r. $o$ dostępie do informacji publicznej. Dz.U. 2001, nr 112, poz. 1198.

\section{Military Courts - the Conditions of Communicating with their Environment}

Keywords: judiciary, communication, army, environment, strategy

Summary. Military judiciary has become a forgotten and omitted type of justice despite the fact that its existence is guaranteed by Polish constitution. Such courts are specific, specialized units which deal with both soldiers and civil army workers. In the times of terrorist threat and of hybrid wars military courts are the ones to provide explicit explanation of the sentences they issue. The goal of the communication is to realize the organization strategy of the courts which aims to make their work effective and just, providing at the same time legal and material conditions to do so. It is possible to reach such goals when the courts have appropriate contact with the stakeholders. When there is no communication with them there appears lack of response, understood as empowering the rights or stakeholders sparing other resources. The purpose of the paper is to identify selected factors influencing the communication of military courts with the environment. The research method used is document analysis.

Translated by Pawet Kocoń

\section{Cytowanie}

Kocoń, P. (2017). Sądy wojskowe - uwarunkowania komunikacji z otoczeniem. Marketing i Zarzadzanie, 1 (47), 123-130. DOI: 10.18276/miz.2017.47-11. 